\title{
Music Technology Software in Adopting Music Teaching Contents
}

Biljana Jeremić ${ }^{1}$, Rajko Pećanac' ${ }^{1}$ Emilija Stankovićz and Tanja Đurđevićc

'University of Novi Sad, Faculty of Education in Sombor

2University of Novi Sad, Academy of Arts, Department of Music

${ }^{3}$ Primary School Sveti Sava in Kikinda

\section{Abstract}

The paper examines the use of music technology software in music classes among younger pupils. The sample consists of 129 fourth grade primary school pupils from Serbia divided into two groups - Experimental (E-65) and Control group (C-64). The experiment was carried out in classes in which pupils' intellectual processes (learning, attention, and memory) were encouraged through the use of music technology software in order to improve their knowledge and abilities. The results of this research show that there is a significant difference between the two groups regarding the level of adopted content. This paper also provides a basis for further research which would be aimed at pupils of all age groups, as users of new technologies in teaching Music.

Key words: educational software; music via technology; pupils' achievement.

\section{Introduction}

The contemporary way of life presupposes the use of new technologies, which requires the use of computers in all spheres of life, including the classroom. Development of the economy, technological progress, and the digitization of educational contents have conditioned the creation of new technologies in education, as well as in music. At the global level, music becomes an important resource in the economy of education,since music classes require additional investment in teaching materials and teacher training. The use of computers as a teaching model is met with great interest (Fletcher-Flinn \& Gravatt, 1995; Jenks \& Springer, 2002). Research shows that the use of new technologies in the adoption of music teaching contents has a positive outcome (Eddins, 1981; Webster, 
2002; Berk, 2008; Dreper, 2008; Bauer, 2014). Fifteen years ago computers were only just starting to appear in the classroom in Serbia. In those days, pupils, teachers, and advisers were often impressed simply by the glamour of using technology as an event in itself. Increased familiarity has now helped us all to realise that music technology is simply a tool which, like all other tools, is only useful if it helps accomplish some grander objective. Mills and Murray (2000) found that the physical constraints of schools' ICT facilities placed limitations on music teachers' use of computer laboratories since these "are rarely equipped with good quality sound cards or attached to MIDI instruments" (Jeremić, 2018, p. 154). Passive and active teaching technologies can be used for learning music in Music teaching (Rudolph, 2004, p. 2). Passive technology includes music reproduction devices, while active technology includes different educational software in which pupils themselves create and learn music at the same time. If learning is authentic, pupils should be engaged in genuine learning problems or tasks that foster the opportunity for them to make connections between new material and prior knowledge (Crawford, 2009, p. 475). It is instructional software that can be used to introduce and strengthen musical concepts from music theory, as an aid to pupils in their independent work and learning. Also, it can be used as an aid to teachers in presenting the teaching material with an aim to improve efficiency in music teaching (Rudolph, 2004, p. 12). In order for this application to be realized, it is necessary that every pupil (or a group of pupils) can use the computer during classes (Pećanac et al., 2011, p. 62). Learning music is therefore authentic, and pupils have an opportunity to connect old and new teaching contents by studying in smaller groups and in a new and interesting way, where the adoption of musical concepts is built on active participation through musical experience.

The term music technology in this research refers to a computer with the following music software installed: MIDI - Musical Instrument Digital Interface, Notation Software - Sibelius and Software for the secondary level - Practica Musica. Therefore, the abbreviation - MTS will be used. At the same time, we should not forget the fact that music technology includes many other music software programmes, but for this research we only used those mentioned above."Music software programs have evolved to better support a constructivist approach to music learning by providing pupils with a technology-mediated environment in which pupils can acquire their knowledge and understanding through unique and more authentic musical experiences" (Lee, 2010, p. 23).

Exploring the benefit of music technology in music classes around the world has induced us to conduct a research in our environment. Namely, according to the national curriculum, music technology is not intended for teaching music in Serbia. Bearing this in mind, we can freely say that our research is pioneering in its field in our country.

The purpose of this paper is to examine the use of music technology software (MTS) in the adoption of teaching contents in music classes. Our interest is focused on the level, quality and extent of the adoption of teaching contents, through MTS 
that has been tailored according to cognitive and musical abilities of the fourth-grade primary school pupils. The practical contribution of this research is the formulation of teaching units, designing, creating, and making it possible to use MTS in the adoption of teaching contents and in training pupils for independent learning. As the research results show, a teaching model such as this one, which includes MTS, can be useful for music teachers both in Serbia and worldwide, because pupils feel familiar with it, it is very new to them, and it motivates them.

\section{Theoretical Framework}

The rapid growth of economic development on a global scale has led teachers to be ready to respond to the challenges of new teaching technologies. Burnard (2007) discusses the important roles of technology and creativity for promoting pedagogical change, arguing for an understanding of as "...teachers need to view the educational experience through the eyes and perspectives of their pupils" ( $p$ 47). "Technological developments have brought with them practical changes in music education by incorporating new hardware and software into teaching and learning practices" (Ho, 2009 , p. 2). In the classroom, technology is a valuable asset in providing alternative strategies to learn about how music works, to foster confidence and creativity and bridge the knowledge gaps that inevitably exist between students with more or less musical experience (Kardos, 2012). Technology as a pedagogical tool can help serve the goals of educational reform by contributing to student learning through challenging tasks, the professionalization of music teachers, and the creation of a culture that supports learning in and out of the classroom in both primary and secondary education. "Computer technology offers a tool with which to change some educational methods and thereby provide a more stimulating learning environment" (Ho, 2004, p. 143).

Teaching technologies have proven efficient in stimulating activity and motivation among pupils (Bauer, 2014; Essays, 2013; Moreno \& Mayer, 2007; Ho, 2009). ICT can best support a constructivist approach to learning music, particularly activities of a creative nature such as composing, improvising, and creative music making (Lee, 2010:1).

As technology has progressed, so has the technology in music teaching. These changes take place in four areas: "(a) the variety of music types, (b) the ease with which the technology can facilitate their application in the classroom, (c) the use of music as a teaching tool in non-music courses across the college curriculum, and (d) the number of music techniques an instructor can implement to improve learning" (Berk, 2008, p. 45). Traditional teaching materials can be presented in electronic form, through the use of multimedia tools, to improve learning. By using them, pupils can combine sound, image, text, colours, and animations in acquiring knowledge and adopting contents. Therefore, the use of multimedia technologies becomes more popular in education as a means to motivate pupils during learning, at the same time providing them with many ways to express their ideas and demonstrate their knowledge (Neo \& Neo, 2004; Ho, 2007), as well as their perception of music in general (Portowitz, 2014, p. 242). 
Generally speaking, teachers use lecturing, metaphors, practical examples, or imitation to teach their pupils music notation. The music teacher needs to teach pupils how to recognize and comprehend music notation, when designing an instructional activity (Yu et al., 2010, p. 151). Music labs have been traditionally used at schools to compose, arrange and practice on MIDI (Musical Instrument Digital Interface) keyboards, using programs such as Finale and Sibelius, well known for their real-time music score interface. However, more recently, new breeds of music software not only include score, but also the capacity to record, edit, and produce sound and video. These include Cubase, Logic, ProTools and FinalCut at the more sophisticated level, but also many free or open source applications can be bundled with computers (Draper, 2008 , p. 2). MIDI enables the user to control musical parameters, thus allowing one to experience and create a great variety of music with a simple keyboard and computer. Computers can also "test" musical skills and provide instant and intuitive feedback. An excellent example of the aural training software for the secondary level is Practica Musica published by Ars Nova (Macintosh and Windows). This program includes a variety of exercises, which can be used both in learning music theory and for listening to music in classes. It includes chords, intervals, melodic and rhythmic dictations and writing sheet music (Rudolph, 2004).

Pupils are "almost without exception" enthusiastic about music technology (Mills \& Murray, 2000). By being familiarized with MTS, the pupils may gain the ability to explore and get to know the world of music on their own. Many music programs are available on the Internet, but the teacher's role is to assist them in searching and using these, and teach them to adopt a critical attitude towards information obtained in this manner. If these programs were integrated in music teaching at schools, they could help improve the motivation of pupils and enhance the quality of learning. Media culture does not have many applications within a school, although it can be the best way to motivate pupils by giving them new tasks and placing them in previously unknown situations that can be only used as a means of their self-improvement (Pohjola \& Johnson, 2009, p. 103).

\section{Methodological Frame of Research}

The aim of this research is to examine the level of adoption of teaching contents in music classes, by fourth-grade primary school pupils, with the help of music technology software (MTS) (MIDI - Musical Instrument Digital Interface, Notation Software Sibelius and Software for the secondary level - Practica Musica).

The research tasks are formulated on the basis of the set aims: (1) - determine whether teaching Music with the help of MTS is more efficient than traditional teaching among younger pupils; (2) - examine the level of adoption of Music content by younger pupils when using MTS.

The research started from the general assumption (hypothesis) that the use of MTS among younger age pupils significantly contributes to the level of efficiency of 
teaching and learning music. Also, it is assumed that all teachers do not use MTS to the same extent in the teaching process. Another assumption was that this research will determine significant differences between the results of two groups: Experimental group (E), where MTS was used and the results represented through five indicators, and Control group (C), where teaching took place in a traditional way.

\section{Methods}

In order to examine the theoretical hypotheses, an experimental (causal) method with parallel groups (E - experimental and C - control) was used in the research. An experimental factor was introduced in the experimental group in the duration of one school year. It consisted of the MTS application in the adoption of contents in music classes. In the control group, a traditional model of teaching was applied, without the use of MTS. The analysis of the research results was done by using a comparative method - a comparison of results obtained in initial and final measurements in the experimental and control group (calculating the level of statistical significance of differences), results of the initial and final testing per groups, $\chi 2$, and univariate and multivariate analyses of variance. After the elimination of non-significant predictors, we have one dependent variable (the use of MTS in music classes), which is measured on two occasions (a repeated effect) and one independent categorical variable - factor (affiliation to an experimental or control group). Given that, in order to determine the significance of the difference between the arithmetic mean, a draft analysis of variance with repeated measurements was used (ANOVA with repeated measurements).

\section{Research Procedures}

In the implementation of this research, it is possible to distinguish several stages. The pre-research stage is a development of the experimental program. The first stage is initial testing (testing of respondents $\mathrm{E}$ and $\mathrm{C}$ ), i.e. an assessment of the level of knowledge through five indicators in order to match groups according to their knowledge level. The observed parameters were: Basics of Music Literacy (BML), Performance of Music by Playing (PMP), Listening to Music (LM), Musical Rhythm (MR), and Performance of Music by Singing (PMS). Testing has been conducted individually with each respondent (the research procedure - an interview) with pre-standardized questions related to music. The testing (in the initial and final measurement) was performed by using the Scale for the Assessment of Vocal Abilities (SAVA) (Jeremić, 2018, p. 147) modified for the requirements of this research with Likert type scales ranging from 1 to 5 , in accordance with the prescribed curriculum for the fourth grade of primary school in Serbia (Education Standards, 2009). It consists of five (V) subscales: I BML (contains tasks concerning the pitch and duration of tones belonging to the $\mathrm{C}$ major scale); Subtest II - PMP (pupils play familiar songs according to sheet music); Subtest III - LM (recognizing learned songs based on a part of a melody (two-stroke) that they listen to); Subtest IV - SM (recognizing and performing the rhythm of a 
song), and Subtest V - PMS (singing the song accompanied by a musical instrument). The initial testing was conducted during September 2015. The second stage was an introduction of the experimental factor in the experimental classes (conducted from October 2015 to April 2016), but only in those classes that dealt with processing a song from sheet music. The third stage was the final testing conducted in May 2016. The examiners in the experimental classes were teachers who were specially trained to work with MTS before the research started.

\section{Description of the Experimental Program}

The purpose of this program is reflected in the implementation of classes in the experimental group with the help of music technology software (MTS), particularly: MIDI - Musical Instrument Digital Interface, Notation Software - Sibelius and Software for the secondary level - Practica Musica. The program combines:

a) a methodical approach to the adoption of contents which encompass the procedures and explanations related to MTS, including the didactic principles of teaching music in particular: gradual acquisition of knowledge, adaptability to the age of pupils, and the level of knowledge of pupils. The teaching contents are associated with listening to music, reading sheet notes, as well as writing sheet music. Within this methodical approach, music education and music literacy take place in stages that are important for learning music: listening, performing, reading and notating (Sloboda, 2007).

b) the structure of the class entails: (1) a motivational part which contains solving particular tasks in order to repeat, determine knowledge, and introduce a new teaching unit of music literacy with the help of Software for the secondary level - Practica Musica (at this age pupils know the tones that belong to the basic $\mathrm{C}$ major scale and the duration of tones, and so the tasks are always set in such a way that pupils can repeat and determine their existing knowledge). It is followed by (2) learning a song according to the sheet music with the help of Notation Software - Sibelius. The methodical approach to learning a song from the sheet music consists of recognizing notes in the sheet music displayed on a monitor, followed by pupils reciting the notes through solmization accompanied by pulsing. Reading the literary text of the song follows the successful performance of the given sheet music, which is followed by (3) playing and singing the song in question on a digital piano. Singing the song according to melodic units accompanied by playing a musical instrument (right hand only); (4) listening to music - in this part of the class, the pupils listen to a song that they have learned by comparing the level of their performance with the performance of their peers from the previous year and (5) determining knowledge of MIDI - Musical Instrument Digital Interface. This part was conducted after three classes of processing songs from the sheet music, where the pupils themselves created melodies based on a given literary text and their acquired knowledge. Pupils had the opportunity to learn through clear guidelines, based on personal ideas and plans. 


\section{Sample description and analysis}

The research sample consisted of the fourth-grade pupils attending general education schools. The research included 129 respondents of three classes in each group (E 65 and $\mathrm{C}-64$ ) who by the location of the school were not evenly selected, but all of them attended city schools (in Sombor and Kikinda, Serbia). Research groups were not formed with regard to the respondents' environments, rather, the initial model included the following categorical predictors (clusters of variables): affiliation to the control or experimental group, gender, professional qualifications of both parents, and social status. As continuous predictors, the overall grade level and Music Education grade level were used. Regarding gender, 68 respondents (52.7\%) were male and 61 (47.3\%) were female. The gender structure of the control and experimental group is similar ( $\chi^{2}$ $(1)=.007 ; \mathrm{p}=.934 ; \mathrm{N}=129)$. In the experimental group there were 35 male $(53.8 \%)$ and $30(46.2 \%)$ female pupils. In the control group there were $33(51.6 \%)$ male and $31(48.4 \%)$ female respondents. In both groups, there were more male respondents, but $\chi 2$ is not statistically significant, since $p>.05$, so we can say that the control and experimental group do not differ in their gender structure. The statistically significant difference between the groups can be seen by examining professional qualifications of the mother. In the experimental group, there is a smaller percentage of mothers (compared to a control group) who have not attended school or have only completed four grades of primary school. We also note that in the experimental group some levels of education of mothers were not at all represented (0, I, II and V), and some were more frequent (IV and VII) than in the control group. Also, the percentage of those with secondary school and faculty degree is higher than in the control group. $\chi^{2}\left(\chi^{2}(6)=26.992 ; \mathrm{p}=.000 ; \mathrm{N}=128\right)$ is highly statistically significant. The difference between the groups can also be seen by examining the professional qualifications of the father. $\chi^{2}$ is significant $\left(\chi^{2}(7)=29.277 ; \mathrm{p}=.000 ; \mathrm{N}=123\right)$. Research groups were also analysed according to their social status. In the control group, the highest percentage was taken up by those with a mediocre social status (45.3\%), followed by those with a good one (34.4\%). In the experimental group, the respondents mostly consisted of those with good social status (53.2\%), then mediocre (29.0\%) and finally with poor (20.3\%). Although some differences in social status between the control and experimental group are visible, they are not statistically significant $\chi 2(2)=4.911 ; p=$ $.086 ; \mathrm{N}=126$ (although closer to significance). We cannot say that the groups differ in their social status nor that one is better or worse than the other.

At the very beginning of the research, before the initial test, groups were matched according to previous music achievement and overall academic achievement. In relation to the analysis of the overall academic achievement of respondents, the analysis of achievement in music classes showed that the results were similar. The differences in percentages among Excellent pupils were $6 \%$ in total, and 2\% among Very good pupils. The overall academic achievement of pupils showed that 5 cells (50.0\%) had the expected frequency less than 5 . The minimum expected frequency was 1.98 . Chi-square was 
not statistically significant, so we could say that these two groups did not differ in the overall academic achievement. Achievement in music classes did not differ much from the overall academic achievement, with the fact that there were no unsuccessful pupils in either group. When it came to the subject Music Education, 3 cells (37.5\%) had the expected frequency less than 5 . The minimum expected frequency was .50 . Chi-square was not statistically significant. Given that the values $\chi^{2}=4.531 ; \mathrm{p}=.210$; $\mathrm{N}=129$ and $\chi 2=7.791 ; \mathrm{p}=.100 ; \mathrm{N}=129$ were not statistically significant, we could say that the groups did not differ in the overall academic achievement and achievement in the subject Music Education. Regarding the relation of intellectual and musical abilities, our analysis is confirmed by another research (Sergeant \& Thatcher, 1974), which highlights high connectivity between these two types of abilities.

\section{Results and Discussion}

Tables 1 to 3 show the results of the variance analysis with repeated measurements (ANOVA with repeated measurements). Tests of effects within the subjects show us the significance of the measurement effect $(F(1)=38.534 ; p=.000)$ and the effect of the interaction of measurement and affiliation with the control or experimental group $(\mathrm{F}(1)=86.171 ; \mathrm{p}=.000)($ Table 1$)$.

Table 1

The Effects of Measuring Affiliation to a Control or Experimental Group

\begin{tabular}{cccccc}
\hline Source & $\begin{array}{c}\text { Sum of } \\
\text { Squares }\end{array}$ & df & M & F & p \\
\hline Measuring & 949.177 & 1 & 949.177 & 38.534 & .000 \\
Group Measuring & 2122.605 & 1 & 2122.605 & 86.171 & .000 \\
Statistical error & 2881.983 & 117 & 24.632 & & \\
\hline
\end{tabular}

Tests of effects between subjects show that the two groups differ by the level of use of MTS in music classes when the average of two measurements is observed. Also, the interaction between measuring and membership in the experimental or control group is significant. The effect of the interaction of measuring and group membership is the effect that is statistically significant, which means that, in addition to the fact that measured parameters of the level of adoption of the content by respondents differ between the two measurements; at the same time there are differences between the two groups of respondents. Based on these statistics we can conclude (Table 2) that the application of different procedures in the implementation of Music teaching (model MTS E-group and traditional model C-group) gives different results. In light of the obtained research results, the general hypothesis is confirmed.

\footnotetext{
${ }^{1}$ Grade system in Serbia consists of a five degree scale: Excellent (the best grade), Very good, Good, Sufficient, Insufficient (the worst grade).
} 
Table 2

Review of results between two measurements in relation to group membership

\begin{tabular}{|c|c|c|c|c|c|}
\hline \multirow{2}{*}{ Measure } & \multirow{2}{*}{ Group } & \multirow{2}{*}{ M } & \multirow{2}{*}{ Statistical error } & \multicolumn{2}{|c|}{ 95\% Confidence interval } \\
\hline & & & & Lower bound & Upper bound \\
\hline \multirow[t]{2}{*}{ BML } & $E$ & 12.972 & .827 & 11.332 & 14.612 \\
\hline & C & 10.098 & .677 & 8.756 & 11.441 \\
\hline \multirow[t]{2}{*}{ PMP } & $E$ & 6.280 & .438 & 5.412 & 7.149 \\
\hline & C & 4.889 & .359 & 4.178 & 5.600 \\
\hline \multirow[t]{2}{*}{ LM } & E & 11.412 & .474 & 10.472 & 12.352 \\
\hline & C & 10.324 & .388 & 9.554 & 11.093 \\
\hline \multirow[t]{2}{*}{ MR } & $E$ & 11.205 & .638 & 9.840 & 12.470 \\
\hline & $C$ & 8.240 & .522 & 7.205 & 9.276 \\
\hline \multirow[t]{2}{*}{ PMS } & $E$ & 11.760 & .739 & 10.294 & 13.225 \\
\hline & C & 9.526 & .605 & 8.326 & 10.726 \\
\hline
\end{tabular}

From Table 2 we see that respondents from the $\mathrm{E}$ and $\mathrm{C}$ group significantly differ in all examined parameters of the SAVA when we consider the average of two measurements.

The mean (M) shows that, when considering the average of two measurements, the respondents from the experimental group have higher scores on each of the examined parameters (a level of adoption of educational content). In addition to the fact that they achieve higher scores in each measuring (in each of the examined parameters) compared to the $\mathrm{C}$ group, $\mathrm{E}$ group respondents record an increase in given parameters, while those from the control group record a decline. Given that these two groups differ in the applied teaching model, this difference in favour of the experimental group can be attributed to the application of a teaching model that includes MTS.

After examining the descriptive statistics (Table 3) of the basics of music literacy (Subtest I) by groups, we see that the experimental group has higher scores $(M=14.126)$ compared to the control group $(M=9.743)$ for both measurements.

The interesting thing is that the mean of the existing knowledge in the area of music literacy of the control group records a decline in the final measurement $(M=9.743)$. According to the mean $(M=6.759)$, respondents in the E group show better results on the test of performing music by playing in the final measurement (Subtest II). Based on the obtained results, we can conclude that significant differences between the $\mathrm{E}$ and $\mathrm{C}$ group have been determined regarding analysed parameters of the SAVA (Subtest II) with high reliability. Distinctive characteristics in terms of achievement are in favour of better results of the E group. Pupils from the experimental group have better achievements on average when it comes to all parameters than pupils from the control group.

Measurement of listening to music (Subtest III) shows a difference between the $\mathrm{E}$ and $\mathrm{C}$ group in favour of the $\mathrm{E}$ group $(\mathrm{M}=12.221)$. In addition to this, even higher $\mathrm{M}$ (12.221) parameters show that the $\mathrm{E}$ group has an increase in results in the final measurement, while the $\mathrm{C}$ group records a small decline in the same measurement $(\mathrm{M}$ $=10.153)$. The results of the measurement show that there are significant differences 
between groups in favour of the E group.

Table 3

Review of differences within groups after the application of MTS

\begin{tabular}{|c|c|c|c|c|c|c|}
\hline \multirow{2}{*}{ Measure } & \multirow{2}{*}{ Group } & \multirow{2}{*}{ Measuring } & \multirow{2}{*}{ M } & \multirow{2}{*}{$\begin{array}{l}\text { Statistical } \\
\text { error }\end{array}$} & \multicolumn{2}{|c|}{ 95\% Confidence interval } \\
\hline & & & & & Lower bound & Upper bound \\
\hline \multirow[t]{4}{*}{ BML } & $E$ & 1 & 11.818 & .876 & 10.080 & 13.556 \\
\hline & & 2 & 14.126 & .844 & 12.452 & 15.801 \\
\hline & C & 1 & 10.453 & .717 & 9.031 & 11.876 \\
\hline & & 2 & 9.743 & .691 & 8.372 & 11.114 \\
\hline \multirow[t]{4}{*}{ PMP } & $E$ & 1 & 5.802 & .494 & 4.822 & 6.781 \\
\hline & & 2 & 6.759 & .443 & 5.880 & 7.638 \\
\hline & C & 1 & 5.111 & .404 & 4.309 & 5.913 \\
\hline & & 2 & 4.668 & .363 & 3.948 & 5.387 \\
\hline \multirow[t]{4}{*}{ LM } & $E$ & 1 & 10.603 & .542 & 9.528 & 11.677 \\
\hline & & 2 & 12.221 & .496 & 11.237 & 13.206 \\
\hline & C & 1 & 10.495 & .444 & 9.615 & 11.374 \\
\hline & & 2 & 10.153 & .406 & 9.347 & 10.959 \\
\hline \multirow[t]{4}{*}{ MR } & $E$ & 1 & 10.177 & .704 & 8.780 & 11.574 \\
\hline & & 2 & 12.232 & .644 & 10.955 & 13.505 \\
\hline & C & 1 & 8.080 & .577 & 6.937 & 9.224 \\
\hline & & 2 & 8.400 & .527 & 7.355 & 9.446 \\
\hline \multirow[t]{4}{*}{ PMS } & $\mathrm{E}$ & 1 & 10.013 & .803 & 8.421 & 11.605 \\
\hline & & 2 & 13.506 & .731 & 12.056 & 14.956 \\
\hline & C & 1 & 9.500 & .657 & 8.196 & 10.803 \\
\hline & & 2 & 9.553 & .599 & 8.365 & 10.740 \\
\hline
\end{tabular}

Mean results of measurements for the subtest which assesses the sense for musical rhythm (Subscale IV) for the E group show an improvement for the E group in the final measurement $(M=12.232)$. The $C$ group records a slight increase in the final measurement of the sense for musical rhythm $(M=8.400)$ (Table 3$)$. The presented data clearly point to the difference between groups in relation to the initial and final measurement, but also to a significant improvement for the E group after the application of the experimental factor $(M=13.506)$. Performance of music by singing shows mean scores that differ according to groups. The $\mathrm{E}$ group records the biggest progress in relation to previous subtests while the $\mathrm{C}$ group also records an improvement, but to a smaller extent $(\mathrm{M}=9.553)$.

Based on the obtained results we can conclude that significant differences have been determined between the $\mathrm{E}$ and $\mathrm{C}$ group according to all analysed parameters of the SAVA with high reliability. Distinctive characteristics in terms of achievement are in favour of better results of the E group, which confirms the hypothesis that this research will determine a significant difference between the results of two groups (E and C). 


\section{Conclusion}

Knowledge of the basics of music literacy, music theory, and music culture is adopted in Serbia through the teaching areas: knowledge and understanding, listening to music, performing music, and creating music (Education Standards, 2009, p. 5760). Definitions should not be the starting point in studying the teaching contents, but understandings should be the result of experiencing music in classes. In that manner, the pupils will adopt knowledge in the field of the teaching contents of music classes more quickly and with a greater level of knowledge. For example, the research conducted by Nompul (2012, p. 299) shows that most learners favour educational excursions, DVDs, computer software, and websites that make learning more enjoyable and memorable, realizing that education is integrated with real life and that teachers are not the authority on the subject matter. The results of this research show that the application of MTS in the teaching process has a positive effect on increasing the level of adoption of knowledge and younger pupils' achievements in Music. This form of teaching shows much better effects in getting to know about musical literacy, listening to music, and performing music by singing or playing. The new technology is closer and more interesting to younger pupils, which is in agreement with the discussions on the effectiveness of teachers in music classes (Savage, 2007, p. 2; Mills, 2005), and produces an idea of introducing pedagogical change by using new technologies. Music teachers need to take pro-active roles in ensuring the quality and status of music at schools. Adapting to resource limitations by the effective use of ICT may achieve positive learning outcomes (Crawford, 2009, p. 486).

The obtained results show that teachers should use MTS as an aid for the acquisition of contents in music teaching. It should also be noted that such teaching cannot replace a direct, or long-term music education, but it can help foster intellectual processes (learning, attention, memory), and increase motivation and creative problem solving, as this research has shown.

The conducted research also had its limitations and shortcomings. Although the research sample was small (N-129), there were also limitations regarding the implementation of the experimental program in terms of technical equipment (computers for each student $\mathrm{N}-65$ ) and the examining method (interview requires concentration and more time). We can say that the results are significant for further research, as they show that the application of the MTS in Music Education setting gives better results in the adoption of the teaching content. This research also shows that the results in the control group are lower at the final compared to the initial measurement. Even if these presented results may seem unusual, they cannot be neglected as they relate to this research. They also justify the results of recent studies in psychology that have shown that the long-term realization of the teaching and learning in the same manner can lead to saturation of pupils with such teaching and to the decline of their motivation for learning and participation in the teaching process (Hellgren \& Lindberg, 2017, p. 420; Gnambs \& Hanfstingl, 2016, p. 1705). 
Based on this research and many others mentioned earlier which claim that the use of technology has a positive impact for the adoption of teaching contents, curriculum change is required if the world of the classroom is to keep pace with the world outside. It is also necessary to have a clearly defined theory which allows teachers to commit themselves intellectually to the change (Cain, 2004, p. 219). They need to be acquainted with the latest teaching methods by studying them, testing them in the classroom, and finally adjusting them to the requirements of their environment.

The results of this research provide a basis for further research which would be aimed towards all pupils, including older ones, as users of new technologies in Music Education teaching, in terms of their needs and motivation for accepting this type of education, and towards teachers as the organizers of the teaching process. Younger pupils are, most of the time, much easier to entertain during classes, so they are usually more flexible in accepting new, innovative resources for work, such as MTS. However, the application of new technologies in Music Education teaching is of great value for the teaching process and, as the results of this research show, should have an even more important role in the adoption and acquisition of pupils' knowledge in Music Education classes, regardless of their age and level of competence.

\section{References}

Bauer, W. I. (2014). Music Learning Today: Digital Pedagogy for Creating, Performing, and Responding to Music. Oxford University Press. https://doi.org/10.1093/acprof:oso/9780199890590.001.0001

Berk, R. A. (2008). Music and music technology in college teaching: Classical to hip hop across the curriculum. International Journal of Technology in Teaching and Learning, 4(1), pp. 45-67. http://www.ronberk.com/articles/2008_music.pdf.

Burnard, P. (2007). Reframing creativity and technology: Promoting pedagogic change in music education. Journal of Music, Technology and Education, 1(1), 37-55. https://doi. org/10.1386/jmte.1.1.37 1

Cain, T. (2004). Theory, technology and the music curriculum. British Journal of Music Education, 21(02), 215-221. https://doi.org/10.1017/S0265051704005650

Crawford, R. (2009). Secondary school music education: A case study in adapting to ICT resource limitations. Australasian Journal of Educational Technology. 25(4), 471-488. https:// doi.org/10.14742/ajet.1124

Draper, P. (2008). Music, Technology and Classroom 2.0. Education Technology Solutions. http:// www98.griffith.edu.au/dspace/bitstream/handle/10072/23933/54832 1.pdf;jsessionid = 9B842E66DA886B428C2FD455455BD636? sequence $=1$.

Eddins, J. M. (1981). A Brief history of computer-assisted instruction in music college. Music Symposium, 21(2), 7-14.

Fletcher-Flinn, C. M., \& Gravatt, B. (1995). The efficacy of computer assisted instruction (CAI): A meta-analysis. Journal of Educational Computing Research, 12(3), 219- 242. https:// doi.org/10.2190/51D4-F6L3-JQHU-9M31 
Gnambs, T., \& Hanfstingl, B. (2016). The Decline of Academic Motivation during Adolescence: An Accelerated Longitudinal Cohort Analysis on the Effect of Psychological Need Satisfaction. Educational Psychology, 36(9), 1698-1712. https://doi.org/10.1080/0144341 $\underline{0.2015 .1113236}$

Ho, W. C. (2004). Attitudes towards information technology in music learning among Hong Kong Chinese boys and girls. British Journal of Music Education, 21(2), 143-161. https:// doi.org/10.1017/S0265051704005662

Ho, W. C. (2007). Music students' perception of the use of multi-media technology at the graduate level in Hong Kong higher education. Asia Pacific Education Review, 8(1), 12-26. https://doi.org/10.1007/BF03025830

Ho, W. C. (2009). The role of multimedia technology in Hong Kong higher education music programs. Visions of Research in Music Education, 13. http://www-usr.rider.edu/ vrme/ v13n1/Vision/Ho.finalfaedits. 01.15.09.pdf.

Hellgren, J., \& Lindberg, S. (2017). Motivating Students with Authentic Science Experiences: Changes in Motivation for School Science. Research in Science \& Technological Education, 35(4), 409-426. https://doi.org/10.1080/02635143.2017.1322572

Jenks, M. S., \& Springer, J. M. (2002). A View of the Research on the Efficacy of CAI. Electronic Journal for the Integration of Technology in Education, 1(2):43-58. http://ejite.isu.edu/ Volume1No2/Jenks.pdf.

Jeremić. B. (2018). Development of the vocal abilities of students of the original innovative methodical approaches in the teaching of music education. Monography. Sombor: Faculty of Education.

Kardos, L. (2012). How music technology can make sound and music worlds accessible to student composers in Further Education colleges. British Journal of Music Education, 29(02), 143-151. https://doi.org/10.1017/S0265051712000186

Lee, B. K. (2010). ICT integration in primary school music education: Experience of pioneering countries and its implications for implementation in Hong Kong. Asia-Pacific Journal for Arts Education, 8(4), 1-28.

Mills, J. (2005). Music in Schools. Oxford University Press.

Mills, J., \& Murray, A. (2000). Music technology inspected: good teaching in Key Stage 3. British Journal of Music Education, 17(02), 129-156. https://doi.org/10.1017/S026505170000022X

Moreno, R., \& Mayer, R. (2007). Interactive multimodal learning environments. Educational Psychology Review, 19(3), 309-326. https://doi.org/10.1007/s10648-007-9047-2

Neo, T. K., \& Neo, M. (2004). Classroom innovation: Engaging students in interactive multimedia learning. Campus-Wide Information Systems, 21(3), 118-124. https://doi. org/10.1108/10650740410544018

Nompula, Y. (2012) An investigation of strategies for integrated learning experiences and instruction in the teaching of creative art subjects. South African Journal of Education, 32(3):293-306. https://doi.org/10.15700/saje.v32n3a579

Pećanac, R., Lambić, D., \& Marić, M. (2011). The influence of the use of educational software on the effectiveness of communication models in teaching. The New Educational Review, 26(4), 60-70. 
Pohjola, K., \& Johnson, E. (2009). Lasten mediakulttuuri ja koulu vuoropuheluun. (Children's media culture and school in interaction). Koulutuksen tutkimuslaitos.

Portowitz, A. (2014). In harmony: A technology-based music education model to enhance musical understanding and general learning skills. ISME-International Journal of Music Education, 32(2), 242-260. https://doi.org/10.1177/0255761413517056

Rudolph, T. E. (2004). Teaching Music with Technology (2nd ed). GIA Publications, Inc.

Savage, J. (2007). Pedagogical strategies for change. In J Finney \& P Burnard (Eds)., Music Education with Digital Technology, (pp. 142-156). Continuum.

Sergeant, D. C., \& Thatcher, G. (1974). Intelligence, Social Status and Musical Abilities. Psychology of Music, 2(2), 3-19. https://doi.org/10.1177/030573567422005

Sloboda, J. A. (2007). The Musical Mind. The Cognitive Psychology of Music (16th ed). Oxford University Press.

Webster, P. (2002). Computer-based technology and music teaching and learning. In R Colwell \& C Richardson (Eds.). The new handbook of research on music teaching and learning. Oxford University Press.

Yu, P. T., Lai, Y. S., Tsai, H. S., \& Chang, Y. H. (2010). Using a Multimodal Learning System to Support Music Instruction. Educational Technology \& Society, 13(3), 151-162.

${ }^{* * *}$ Education standards for the end compulsory education. (2009). Ministry of Education of the Republic of Serbia, Institute for the Evaluation of Education Quality, 57-60.

\section{Biljana Jeremić,}

Faculty of Education in Sombor

University of Novi Sad

Podgorička 4 . 25000 Sombor, Serbia

biljana.jeremic@pef.uns.ac.rs

\section{Rajko Pećanac}

Faculty of Education in Sombor

University of Novi Sad

Podgorička 4 . 25000 Sombor, Serbia

rajkopecanac13@gmail.com

\section{Emilija Stanković,}

Academy of Arts, Department Of Music

University of Novi Sad

Djure Jaksica 7, 21000 Novi Sad, Serbia

emast59@gmail.com

\section{Tanja Đurđević}

Primary school Sveti Sava Kikinda

Svetosavska 66, 23300 Kikinda, Serbia

tanja.djurdjevic@gmail.com 


\section{Softveri za glazbenu tehnologiju u usvajanju nastavnih sadržaja na satima glazbene kulture}

\section{Sažetak}

U radu se istražuje korištenje softvera za glazbenu tehnologiju u usvajanju nastavnih sadržaja i realizaciji nastave glazbene kulture. Uzorak se sastoji od 129 učenika četvrtoga razreda osnovne škole podijeljenih u dvije skupine, eksperimentalni ( $E$ - 65 učenika) i kontrolni ( $K$ - 64 učenika). Eksperiment se temelji na konceptu nastave u kojoj se učenici potiču na poticanje intelektualnih procesa (učenje, pažnja, pamćenje) korištenjem glazbene tehnologije. Rezultati ove studije pokazuju da postoji značajna razlika između dviju skupina s obzirom na razine usvojenoga sadržaja. Ovaj je rad temelj daljnjih istraživanja koja bi bila usmjerena na učenike svih dobnih skupina kao korisnike novih tehnologija u nastavi glazbene kulture.

Ključne riječi: glazba uporabom tehnologije; obrazovni softver; postignuća učenika

\section{Uvod}

Suvremeni način života doveo je do uporabe nove tehnologije, što podrazumijeva korištenje računala u svim sferama života pa tako i u nastavnom procesu. Razvoj ekonomije, tehnološki napredak i digitalizacija nastavnih sadržaja doveli su do stvaranja novih tehnologija u glazbi. Na globalnoj razini, glazba postaje važno sredstvo u obrazovnoj ekonomiji jer nastava glazbe zahtijeva dodatna ulaganja u nastavne materijale i izobrazbu nastavnika. Korištenje računala kao modela poučavanja od velikog je interesa upravo zbog pojave novih tehnologija (Fletcher-Flinn \& Gravatt, 1995; Jenks \& Springer, 2002). Istraživanja pokazuju da se u nastavi glazbe prednost daje uporabi novih tehnologija u usvajanju nastavnih sadržaja (Eddins, 1981; Berk, 2008; Dreper, 2009; Bauer, 2014). Prije petnaest godina računala su se tek počela pojavljivati u školama u Srbiji, a zatim su učenici, nastavnici i savjetnici često bili impresionirani mogućnostima uporabe računalne tehnologije u nastavnom procesu. Upoznavanje $s$ glazbenom tehnologijom pomoglo nam je shvatiti da je riječ o jednostavnom alatu koji je, kao i svi drugi alati, koristan samo ako pomaže u postizanju višega cilja. Mills i Murray (2000) su otkrili da su školski IT kabineti zbog prostornih nedostataka ograničili korištenje računala kao nastavnoga pomagala u nastavi glazbe jer su „rijetko 
opremljeni kvalitetnim zvučnim karticama ili priključeni na MIDI instrumente”. Prema Rudolfu (Rudolph, 2004, str. 2), pasivne i aktivne nastavne tehnologije mogu se koristiti u nastavi glazbene kulture za učenje glazbe. Pasivna tehnologija uključuje uređaje za reprodukciju glazbe, dok aktivne uključuju različite obrazovne programe iz kojih studenti istovremeno stvaraju i uče glazbu. Kao što Crawford ističe (2009, str. 475), ako je učenje autentično, učenici trebaju biti uključeni u stvarne probleme učenja ili zadatke koji im omogućuju da naprave vezu između novoga materijala i prethodnoga znanja. Upravo je program za poučavanje (instrukcijski softver), kao što Rudolph također ističe, (2004, str. 12) moguće upotrijebiti za uvođenje i jačanje glazbenih koncepata u teoriji glazbe, za pomoć učenicima u samostalnom radu i učenju ili kao dodatak učiteljima u predstavljanju materijala u cilju poboljšanja učinkovitosti nastave glazbe. Da bi ova primjena mogla biti ostvarena, potrebno je da se nastava odvija u uvjetima u kojima svaki student (ili grupa studenata) može koristiti računalo tijekom nastave (Pećanac, R., Lambić, D. i Marić, M., 2011, str. 62). Usvajanje znanja tako je autentično i učenici imaju priliku povezati stare i nove nastavne sadržaje, učiti u manjim grupama i na nov i zanimljiv način gdje se usvajanje glazbenih koncepata temelji na aktivnom sudjelovanju kroz glazbeno iskustvo.

Na temelju iznesenoga, u ovom radu pojam glazbene tehnologije uključuje računalo koje sadrži glazbeni softver: MIDI - digitalno sučelje za glazbene instrumente, softver za notaciju - Sibelius i softver za sekundarnu razinu - Practica Musica, a mi smo ih nazvali softverima za glazbenu tehnologiju (SGT). Programi za glazbeni softver razvijeni su kako bi bolje podupirali konstruktivistički pristup učenju glazbe u tehnološkom okruženju gdje učenici mogu razumjeti glazbu kroz jedinstvena i autentična glazbena iskustva (Lee, 2010, str. 23).

Istraživanje prednosti glazbene tehnologije u nastavi glazbe u svijetu potaknulo je istraživanja u našoj sredini. Naime, prema nacionalnom kurikulu, glazbena tehnologija nije namijenjena nastavi glazbe u Srbiji. Imajući to na umu, slobodno možemo reći da je naše istraživanje prvo u ovom području u našoj zemlji.

Svrha ovoga rada je provjeriti korištenje softvera glazbene tehnologije (SGT) za stjecanje nastavnih sadržaja nastave glazbene kulture. Naš interes usmjeren je na razinu, kvalitetu i opseg usvajanja nastavnih planova i programa glazbene kulture pomoću SGT-a, koji je prilagođen mentalnim i glazbenim sposobnostima učenika 4. razreda osnovne škole. Praktični doprinos provedenoga istraživanja je izrada nastavnih jedinica, dizajn, stvaranje i mogućnost primjene SGT-a u usvajanju nastavnih sadržaja i osposobljavanje studenata za samostalno učenje. Vjerujemo da (kao što su rezultati istraživanja pokazali) takav model poučavanja koji uključuje SGT može biti koristan za nastavnike glazbe diljem svijeta jer je blizak učenicima, nov i vrlo motivirajuć.

\section{Teorijski okvir istraživanja}

Ubrzan porast ekonomskoga razvoja na globalnoj razini naveo je učitelje da budu spremni odgovoriti na izazove novih nastavnih tehnologija. Kao što ističe Burnard 
(2007), većina glazbenih pedagoga slaže se da se osnovni cilj prakse glazbenoga obrazovanja treba izvoditi u novim okruženjima e-učenja. Novi razvoji u e-učenju i sve sofisticiranije učenje kroz novu tehnologiju imali su veliki utjecaj na implementaciju informacijsko-komunikacijskih tehnologija (IKT) kao obrazovnih misija u tjelesnom odgoju (Ho, 2009, str. 2). U razredu je tehnologija važan alat jer pruža alternativne strategije za učenje o tome kako glazba funkcionira, potiče samopouzdanje i kreativnost te prevladava praznine u znanju koje nužno postoje kod učenika s više ili manje glazbenoga iskustva (Kardos, 2012). Uporabom tehnologije kao pedagoških sredstva i pomagala tako što poticajnim zadatcima, edukacijom učitelja glazbe i stvaranjem kulture koja podržava učenje u učionici i izvan nje u osnovnim i srednjim školama može pomoći u ostvarenju ciljeva obrazovne reforme i procesu učenja . Računalna tehnologija nudi alat koji mijenja neke obrazovne metode i time osigurava poticajnije okruženje za učenje (Ho, 2004, str. 143). Izazov nastavnih tehnologija pokazao se učinkovitim za poticanje aktivnosti i motivaciju za učenike (Bauer, 2014; Essays, 2013; Ho, 2009). IKT može najbolje podržati konstruktivistički pristup učenju glazbe, posebno aktivnosti kreativne prirode, kao što su skladanje, improvizacija i kreativno stvaranje glazbe (Lee, 2010, str. 1).

Kako je tehnologija napredovala, tako se mijenjao i način njezine primjene u nastavi glazbe. Te promjene, prema Berku, (2008, str. 45), dogodile su se u četiri područja: „(a) različite vrste glazbe, (b) lakoća usvajanja materijala proizvedenih uporabom tehnologije u učionici (c) uporaba glazbe kao nastavnoga alata na neglazbenim satima unutar nastavnoga plana i programa fakulteta i (d) broj glazbenih tehnika koje nastavnik može primijeniti za poboljšanje učenja" (Berk, 2008, str. 45). Ove promjene uvjetovale su i korištenje novih nastavnih materijala i u tradicionalnim načinima učenja. Tradicionalni nastavni materijali mogu se prezentirati u elektroničkom obliku korištenjem multimedijskih alata za poboljšanje učenja. Koristeći ih, učenici mogu kombinirati zvuk, sliku, tekst, boje i animacije u stjecanju znanja i usvajanju sadržaja što nas vodi do uporabe multimedijalnih tehnologija koje postaju sve popularanije $\mathrm{u}$ obrazovanju kao sredstvo motiviranja učenika tijekom učenja, a istodobno im pruža i mnogo načina za izražavanje svoje ideje i prikazivanje svojega znanja (Neo \& Neo, 2004; Ho, 2007) kao i percepciju glazbe općenito (Portowitz, 2014, str. 242).

Općenito govoreći, nastavnici koriste predavanje, metafore, praktične primjere ili imitaciju kako bi naučili učenike glazbenoj notaciji. Nastavnik glazbe, pri dizajniranju neke instrukcijske aktivnosti, mora učiti učenike kako prepoznati i razumjeti glazbeni zapis (Yu, Lai, Tsai \& Chang, 2010, str. 151). Glazbeni laboratoriji tradicionalno se koriste u skladanju, aranžiranju i obuci na tipkovnicama MIDI (digitalno sučelje za glazbene instrumente) pomoću programa kao što su Finale ili Sibelius, koji su poznati po notnom sučelju u stvarnom vremenu. Međutim, u novije vrijeme, nove vrste glazbenoga softvera ne uključuju samo zapisivanje nota, nego i mogućnost snimanja, uređivanja i proizvodnju zvuka i videa. To uključuje Cubase, Logic, ProTools i FinalCut na višoj razini, kao i mnoge besplatne aplikacije koje se mogu povezati s računalima 
(Draper, 2008, str. 2). MIDI omogućuje korisniku da kontrolira glazbene parametre i tako doživi i stvara veliku glazbenu raznolikost samo s tipkovnicom i računalom. Računala također mogu testirati glazbene vještine i pružiti trenutačne i intuitivne povratne informacije. To otvara vrata razvoju bogatstva softvera dizajniranoga za pedagogiju glazbenih vještina. Izvrstan primjer softvera za slušnu obuku učenika srednje škole je Practica Musica u izdanju Ars Nove (za Macintosh i Windows). Ovaj program uključuje mnoštvo različitih vježbi koje se mogu koristiti za učenje teorije glazbe i slušanje glazbe na satu. Uključuje akorde, intervale, melodijske i ritmičke diktate te pisanje nota (Rudolph, 2004).

Učenici su „gotovo bez izuzetka” oduševljeni glazbenom tehnologijom (Mills \& Murray, 2000). Uvođenjem SGT-a, učenik ima priliku istražiti i otkriti svijet glazbe. Mnogi glazbeni programi dostupni su na internetu, ali uloga je nastavnika da im pomognu u pretraživanju i korištenju i da ih nauče kritičkom odnosu prema informacijama koje tako dobivaju. U svakom slučaju, ako bi se ti programi integrirali u poučavanje glazbene kulture u školama, mogla bi se poboljšati motivacija učenika i kvaliteta učenja. Medijska kultura u nastavnom procesu nema veliku primjenu. Međutim, ona može najbolje motivirati učenike postavljajući im nove zadatke i stavljajući ih u do tada nepoznate situacije koje im mogu koristiti kao sredstvo vlastitoga usavršavanja (Pohjola i Johnson, 2009, str. 103).

\section{Metodički okvir istraživanja}

Cilj istraživanja je ispitati stupanj prihvaćenosti sadržaja predmeta glazbene kulture učenika IV. razreda osnovne škole pomoću softvera za glazbenu tehnologiju (MIDI digitalno sučelje glazbenoga instrumenta, softvera za notaciju - Sibelius i Softvera za srednju razinu - Practica Musica).

Na temelju cilja formulirani su istraživački zadatci: (1) - utvrditi je li poučavanje glazbene kulture uporabom SGT-a učinkovitije od tradicionalne nastave; (2) - ispitati razinu usvajanja glazbene kulture učenika pomoću SGT-a.

Istraživanje je počelo od opće pretpostavke (hipoteze) da primjena SGT-a značajno pridonosi učinkovitosti nastave glazbene kulture i učenja učenika nižih razreda osnovne škole, ali i da SGT ne primjenjuju jednako svi nastavnici u nastavi. Iz posebne pretpostavke proizlazi i da će se istraživanjem utvrditi kako postoji značajna razlika u rezultatima između dviju skupina: eksperimentalna (E) skupina u kojoj je primijenjeno SGT i rezultati predstavljeni kroz pet pokazatelja i kontrolne (K) skupine u kojima su nastavne jedinice realizirane na tradicionalan način.

\section{Metode}

$\mathrm{U}$ svrhu ispitivanja teorijskih hipoteza $\mathrm{u}$ istraživanju je korištena eksperimentalna metoda (uzročna) s paralelnim skupinama (E - eksperimentalna i K - kontrolna skupina). U eksperimentalnu skupinu uveden je eksperimentalni faktor koji je trajao jednu školsku godinu. Sastoji se od primjene SGT-a u usvajanju sadržaja na satima glazbene kulture. U kontrolnoj skupini primijenjen je tradicionalni model poučavanja 
bez korištenja SGT-a, pri čemu je analiza rezultata provedena usporednom metodom - uspoređivanje dobivenih rezultata početnih i završnih mjerenja u eksperimentalnoj i kontrolnoj skupini (izračun razine statističke značajnosti razlike), rezultata početnoga $\mathrm{i}$ završnoga ispitivanja po skupinama. $\chi 2$, univarijatna i multivarijatna analiza varijance. Nakon isključenja neznačajnih prediktora postoji jedna zavisna varijabla (korištenje SGT-a na satima glazbene kulture) mjerena u dva navrata (ponovljeni učinak) i jedan neovisni kategorički varijabilni faktor (koji pripada eksperimentalnoj ili kontrolnoj skupini). Na taj način, kako bi se utvrdila značajnost razlika između aritmetičkih značenja, korištena je analiza varijance s ponovljenim mjerenjima (ANOVA $s$ ponovljenim mjerenjima).

\section{Postupci istraživanja}

U realizaciji ovoga istraživanja moguće je razlikovati nekoliko faza. Predfaza je uključivala razvoj eksperimentalnoga programa. Prva faza podrazumijevala je početno testiranje (ispitivanje ispitanika skupine $\mathrm{E}$ i K), odnosno procjenu razine znanja kako bi se skupine izjednačile prema razini znanja. Parametri istraživanja bili su: osnove glazbene pismenosti (OGP), izvođenje glazbe sviranjem (IGS), slušanje glazbe (SG), glazbeni ritam (GR) i izvođenje glazbe pjevanjem (IGP). Testiranje je provedeno pojedinačno sa svakim od ispitanika (istraživački postupak - intervju) s unaprijed standardiziranim sadržajem po glazbenim pitanjima. Početna i završna mjerenja izvršena su pomoću Skale za procjenu vokalnih vještina (SPVV) (Jeremić, 2018, str. 147), koja je modificirana za potrebe ovoga istraživanja: pripada Likertovoj skali (od 1 do 5) i u skladu je s nastavnim planom i programom za IV. razred osnovne škole (Obrazovni standardi, 2009). Sastoji se od pet podskala: I. - OGP (sadrži zadatke o visini i trajanju C bodova ljestvice); II. podtest - IGS (učenici sviraju dobro poznate pjesme iz notacije); III. podtest - SG (prepoznavanje naučenih pjesama na temelju dijela melodije (dva) koje slušaju); IV. podtest - GR (prepoznavanje i izvođenje ritma pjesme) i V. podtest IGP (pjevanje pjesme uz instrument. Početno ispitivanje provedeno je u rujnu 2015. godine. Druga faza bila je uvođenje eksperimentalnih čimbenika u eksperimentalne odjele (od listopada 2015. do travnja 2016.) i to samo na satima na kojima je nastavna jedinica bila obrada pjesme iz notnoga teksta. Treća faza je završni test proveden u svibnju 2016. godine. Stručnjaci u eksperimentalnim odjelima bili su učitelji posebno osposobljeni za rad sa SGT prije početka istraživanja.

\section{Opis eksperimentalnoga programa}

Svrha ovoga programa ogleda se u realizaciji nastave u eksperimentalnoj skupini pomoću softvera za glazbenu tehnologiju (SGT): MIDI - digitalno sučelje glazbenoga instrumenta, softver za notaciju - Sibelius i softver za sekundarnu razinu - Practica Musica. Program objedinjuje:

a) metodički pristup usvajanju sadržaja koji uključuje postupke i objašnjenja vezana uz SGT, uključujući posebno didaktička načela poučavanja glazbe: postupno prihvaćanje znanja, pristup prilagođen dobi i razinu znanja učenika. Sadržaji za učenje povezani su 
sa slušanjem i čitanjem nota kao i notnoga bilježenja. U ovome metodičkom pristupu glazbeno obrazovanje i glazbena pismenost odvijaju se u fazama koje su važne za učenje glazbe: slušanje, izvođenje, čitanje i bilježenje (Sloboda, 2007).

b) struktura sata uključivala je: 1. motivacijski dio koji je uključivao rješavanje određenih zadataka kako bi se ponovilo, identificiralo znanje i uvelo ga u novu nastavnu jedinicu pomoću softvera za srednju razinu - Practica Musica (u ovoj dobi učenici znaju osnovne tonove $\mathrm{C}$-dur ljestvice, trajanje tonova te se i zadatci uvijek postavljaju tako da učenici ponavljaju i određuju postojeće znanje, nakon čega slijedi (2) učenje pjesme pomoću nota i softvera za notaciju - Sibelius. Metodički postupak učenja pjesme iz nota sastoji se od prepoznavanja notnih znakova notnoga zapisa koji se nalazi na zaslonu, zatim učenici izgovaraju note solmizacijom uz taktiranje. Nakon uspješno izvedenoga danog notnog zapisa prelazi se na čitanje literarnoga teksta pjesme, a zatim (3) sviranje i pjevanje iste pjesme - pjevanje pjesme po melodijskim cjelinama uz sviranje na instrumentu (samo desnom rukom), (4) slušanje glazbe - u ovom dijelu sata učenici slušaju pjesmu koju su naučili uspoređujući svoju izvedbu s nastupima svojih vršnjaka iz prethodne godine i (5) utvrđivanje znanja MIDI digitalnoga sučelja za glazbene instrumente, ovaj je dio implementiran nakon tri sata obrade pjesme iz nota, gdje su učenici sami stvorili melodije na temelju danog književnoga teksta i stečenoga znanja. Učenici su imali priliku učiti kroz jasne upute na temelju osobnih ideja i planova.

\section{Opis uzorka i analiza}

Uzorak istraživanja čine učenici IV. razreda općeobrazovne osnovne škole. Istraživanjem je obuhvaćeno 129 učenika u tri razreda u svakoj skupini (E - 65 i K - 64) iz Sombora i Kikinde - Srbija. Istraživačke skupine nisu oblikovane prema okruženju ispitanika, već su kao kategorički prediktori (grupne varijable) u početni model uključeni: pripadnost kontrolnoj ili eksperimentalnoj skupini, spol, stručna sprema oca i majke i društveni status. Kao kontinuirani prediktori uvršteni su opći uspjeh i uspjeh iz predmeta Glazbena kultura. Ukupno 68 ispitanika (52,7 \%) bilo je muškog, a 61 (47,3 \%) ženskog spola. Cjelokupna spolna struktura kontrolne i eksperimentalne skupine je slična $(\chi 2(1)=0.007 ; \mathrm{p}=.934 ; \mathrm{N}=129)$. U eksperimentalnoj skupini muških je 35 (53,8 \%), a ženskih 30 (46,2 \%). U kontrolnoj skupini muških je 33 (51,6 \%) ženskih $31(48,4 \%)$. U obje skupine ima nešto više muških ispitanika $\chi 2$ koji nisu statistički značajni, jer $\mathrm{p}>.05$, pa se može reći da se kontrolna i eksperimentalna skupina ne razlikuju po spolnoj strukturi. Uzorak kontrolne i eksperimentalne skupine statistički se značajno razlikuje prema stručnoj spremi majke. U eksperimentalnoj skupini manji je postotak majki (u usporedbi s kontrolnom skupinom) koje nemaju školu ili su završile samo četiri razreda osnovne škole. Napominjemo da u eksperimentalnoj skupini neki stupnjevi obrazovanja majki uopće nisu zastupljeni (0, I., II. i V.), a neki su češći (IV. i VII.) nego u kontrolnoj skupini. Također, postotak onih koji imaju srednju školu i fakultet veći je nego u kontrolnoj skupini. $\chi^{2}\left(\chi^{2}(6)=26,992 ; \mathrm{p}=.000 ; \mathrm{N}=128\right) \mathrm{i}$ 
statistički značajan. Uzorak kontrolne i eksperimentalne skupine statistički se značajno razlikuje prema stručnoj spremi oca $\chi 2$ je značajan $\chi 2(7)=29.277 ; \mathrm{p}=.000 ; \mathrm{N}=123$. Istraživačke su skupine također analizirane prema njihovom društvenom statusu. $U$ kontrolnoj skupini najveći je postotak onih srednjega socijalnog statusa $(45,3 \%)$, a slijede oni s dobrim (34,4\%). U eksperimentalnoj skupini uglavnom su oni dobroga socijalnog statusa (53,2 \%), zatim srednjeg (29,0 \%) i na kraju siromašni (20,3 \%). Iako su neke razlike u socijalnom statusu između kontrolne i eksperimentalne skupine vidljive, one nisu statistički značajne $\chi^{2}(2)=4.911 ; \mathrm{p}=0,086 ; \mathrm{N}=126$ (iako bliže značajnosti). Ne možemo reći da se skupine razlikuju po svojem društvenom statusu niti da je neka bolja ili lošija.

Na samom početku istraživanja, prije početnoga testa, skupine su bile usklađene prema uspjehu iz Glazbene kulture i općem uspjehu. U usporedbi s analizom općega uspjeha ispitanika, analiza uspješnosti na predmetu Glazbena kultura pokazuje da su rezultati slični. Razlika u postotcima između izvrsnih je samo $6 \%$, vrlo dobrih $2 \%$. Ukupni uspjeh učenika pokazuje da 5 ćelija (50,0 \%) ima očekivanu učestalost manju od 5. Minimalna očekivana frekvencija je 1,98. hi-kvadrat nije statistički značajan, pa možemo reći da se dvije skupine ne razlikuju u općem uspjehu. Uspjeh iz predmeta Glazbena kultura ne razlikuje se mnogo od općega uspjeha, no ni u jednoj skupini nema nedovoljnih rezultata. Uz uspjeh iz predmeta Glazbena kultura 3 ćelije (37,5 \%) imaju očekivanu frekvenciju manju od 5. Minimalna očekivana frekvencija je 0,50 . hi-kvadrat nije statistički značajan. S obzirom da vrijednosti $\chi^{2}=4,531 ; p=, 210$; $N=129$ i $\chi^{2}=7,791 ; p=0,100 ; N=129$ nisu statistički značajne možemo reći da se skupine ne razlikuju prema općem uspjehu i uspjehu iz Glazbene kulture. Govoreći o odnosu intelektualnih i glazbenih sposobnosti, našu analizu potvrđuje i drugo istraživanje (Sergeant i Thatcher, 1974), koje ističe visoku korelaciju između ove dvije vrste sposobnosti.

\section{Rezultati i rasprava}

Tablice od broja 1 do broja 3 daju rezultate analize varijance s ponovljenim mjerenjima (ANOVA s ponovljenim mjerenjima). Testovi učinaka unutar ispitanika pokazuju nam značaj učinka mjerenja $(\mathrm{F}(1)=38,534, \mathrm{p}=0,000)$ i učinak mjerne interakcije $\mathrm{i}$ pripadnosti kontrolnoj ili eksperimentalnoj skupini $(\mathrm{F}(1)=86,171, \mathrm{p}=0,000)$ (tablica 1).

\section{Tablica 1.}

Testovi učinaka među ispitanicima pokazuju da se dvije skupine razlikuju po stupnju korištenja SGT-a na satima Glazbene kulture kada se promatra prosjek dvaju mjerenja. Također, značajna je interakcija između mjerenja i pripadnosti eksperimentalnoj ili kontrolnoj skupini. Utjecaj interakcije mjerenja i interakcije između skupina je učinak koji je statistički značajan, što znači da su osim mjerenja parametara razine prihvaćenosti sadržaja ispitanika razlike između dva mjerenja različite, ali istodobno postoje razlike između dviju skupina ispitanika. Na temelju navedenih statističkih podataka može 
se zaključiti (tablica 2) da primjena različitih metoda u realizaciji nastave Glazbene kulture (model SGT E skupine i tradicionalna skupina K) daje različite rezultate. $\mathrm{U}$ kontekstu dobivenih rezultata istraživanja potvrđena je opća hipoteza.

Tablica 2.

Iz tablice 2 vidimo da se ispitanici iz skupina $\mathrm{E}$ i $\mathrm{K}$ značajno razlikuju od svih promatranih parametara SPVV-a kada se uzima prosjek dvaju mjerenja. Srednja vrijednost (AS) ukazuje da ispitanici iz eksperimentalne skupine pri promatranju prosjeka dvaju mjerenja imaju više rezultate u svakom promatranom parametru (razina usvojenosti nastavnih sadržaja). Ispitanici iz skupine $\mathrm{E}$, osim što u svakom mjerenju imaju više rezultate od kontrolne skupine (u svakom promatranom parametru), $\mathrm{u}$ drugom mjerenju bilježe porast zadanih parametara, dok oni iz kontrolne skupine bilježe pad. Budući da se ove dvije skupine razlikuju prema primijenjenom modelu poučavanja, ta razlika u korist eksperimentalne skupine može se pripisati primjeni modela poučavanja koji uključuje SGT.

Ispitivanjem deskriptivne statistike (tablica 3) osnove glazbene pismenosti (podtest I) u skupinama možemo vidjeti da eksperimentalna skupina ima više rezultate (AS = $14,126)$ u odnosu na kontrolnu skupinu (AS $=9,743)$ za oba mjerenja.

\section{Tablica 3.}

Zanimljivo je da aritmetička sredina postojeće glazbene pismenosti kontrolne skupine bilježi smanjenje na konačnom mjerenju (AS $=9,743)$ u odnosu na početno mjerenje. $S$ druge strane, ispitanici iz E skupine prema aritmetičkoj sredini $(A S=6,759)$ pokazuju bolje rezultate na testu provjere izvođenja glazbe sviranjem u konačnom mjerenju (podtest II). Na temelju dobivenih rezultata može se zaključiti da su značajne razlike između skupina E i K određene prema analiziranim parametrima SPVV (podtest II) $\mathrm{s}$ visokom pouzdanošću zaključka. Različiti atributi postignuća idu u korist boljih rezultata E skupine. Učenici iz eksperimentalne skupine imaju, u prosjeku, bolja postignuća kada su u pitanju svi parametri od učenika iz kontrolne skupine.

Mjerenje slušanja glazbe (podtest III) pokazuje razliku između E i K skupina u korist E skupine ( $\mathrm{AS}=12,221)$. Također, pokazuje $\mathrm{s}$ još većim parametrima $\mathrm{AS}$ da skupina $\mathrm{E}$ povećava rezultate na konačnom mjerenju $(\mathrm{AS}=12,221)$, dok skupina $\mathrm{K}$ bilježi vrlo malo smanjenje na istom mjerenju (AS $=10,153)$. Rezultati mjerenja pokazuju da postoje značajne razlike između skupina u korist $\mathrm{E}$ skupine.

Rezultati AS merenja na podtestu procjene osjećaja za glazbeni ritam (podtest IV) za skupinu E pokazuju napredak skupine E na konačnom mjerenju (AS = 12,232). K grupa je zabilježila blagi porast u konačnom mjerenju osjećaja za glazbeni ritam (AS $=8,400)$ (tablica 3). Prikazani podatci (podtest V) jasno pokazuju razliku između skupina u odnosu na početno i završno mjerenje, ali i značajan rast E skupine nakon eksperimentalnoga faktora (AS $=13,506$ ). Izvođenje glazbe pjevanjem pokazuje AS koja se razlikuje prema skupinama. E skupina je zabilježila najveći napredak u odnosu 
na prethodne podtestove, dok je skupina $\mathrm{K}$ također zabilježila porast, ali u malom opsegu $(\mathrm{AS}=9,553)$.

$\mathrm{Na}$ temelju dobivenih rezultata može se zaključiti da su utvrđene značajne razlike između skupina E i K prema analiziranim parametrima SPVV-a s visokom pouzdanošću zaključka. Posebni atributi postignuća u korist su boljih rezultata E skupine, što potvrđuje i objavljenu hipotezu: pretpostavlja se da postoje statistički značajne razlike u primjeni SGT-a u nastavnom procesu kada je riječ o razini usvojenosti nastavnoga sadržaja učenika E i K skupine prema svim parametrima SPVV-a.

\section{Zaključak}

Znanje iz osnova glazbene pismenosti, glazbene teorije i glazbene kulture u Republici Srbiji usvaja se kroz nastavna područja: znanje i razumijevanje, slušanje glazbe, izvođenje glazbe i glazbeno stvaralaštvo (Obrazovni standardi, 2009). Definicije ne bi trebale biti polazište u proučavanju nastavnih sadržaja, već rezultat glazbenoga iskustva na nastavnim satima. Ovim pristupom učenici će brže usvojiti znanja iz područja nastavnih sadržaja predmeta Glazbena kultura. Na primjer, istraživanje Nompula (2012, str. 299) pokazuje da učenici preferiraju edukativne izlete, DVD-ove, računalni softver i mrežne stranice koje učenje čine ugodnim i nezaboravnim, shvaćajući da je obrazovanje integrirano sa stvarnim životom i da nastavnici nisu autoritet predmeta. Rezultati ovoga istraživanja pokazuju da primjena SGT u nastavnom procesu pozitivno utječe na povećanje razine stjecanja znanja i uspjeha mlađih učenika u području glazbene kulture. Ova vrsta nastave pokazuje mnogo bolje učinke u učenju glazbene pismenosti, slušanju glazbe, izvođenju glazbe pjevanjem i sviranjem jer se učenici sve više zanimaju za tehnologiju, što je u skladu s raspravama o učinkovitosti nastavnika u glazbenom obrazovanju (Savage, 2007, str. Mills, 2005) koje donose ideju uvođenja pedagoških promjena korištenjem novih tehnologija. Nastavnici glazbe moraju imati proaktivnu ulogu kako bi osigurali kvalitetu i status predmeta Glazbena kultura u školama. Prilagodba ograničenja resursa s učinkovitim korištenjem IKT-a može dovesti do pozitivnih ishoda učenja (Crawford, 2009, str. 486).

Dobiveni rezultati pokazuju da bi nastavnici trebali koristiti SGT kao pomoćno sredstvo u usvajanju sadržaja iz nastave glazbe. Također treba napomenuti da takvo poučavanje ne može zamijeniti izravnu, dugotrajnu glazbenu edukaciju, ali može pomoći u poticanju intelektualnih procesa (učenje, pažnja, pamćenje) i kao sredstvo motiviranja i kreativnoga rješavanja problema što je ovo istraživanje i pokazalo.

Međutim, provedeno istraživanje imalo je svoja ograničenja. Osim što je uzorak bio malen $(\mathrm{N}=129)$, u eksperimentalnom programu postojala su tehnička ograničenja u smislu računalne opreme škola (računala za svakog učenika $\mathrm{N}=65$ ) kao i metoda testiranja (intervju kao metoda zahtijeva koncentraciju i više vremena). Unatoč tim ograničenjima, možemo reći da su dobiveni rezultati značajni za daljnja istraživanja jer pokazuju da korištenje SGT-a u nastavi Glazbene kulture daje bolje rezultate s obzirom na usvajanja gradiva. Rezultati istraživanja pokazali su da su rezultati u kontrolnoj 
skupini bili slabiji u konačnom mjerenju u usporedbi s početnim mjerenjem. Ma koliko prikazani rezultati djelovali neuobičajeno, oni se ne mogu zanemariti jer se odnose na konkretno istraživanje. Oni također opravdavaju rezultate nedavnih istraživanja u psihologiji koji su pokazali da dugoročno ostvarenje poučavanja i učenja učenika na isti način može dovesti do zasićenja učenika s takvim učenjem i do smanjenja njihove motivacije za učenjem i sudjelovanjem u nastavi (Hellgren i Lindberg, 2017, str. 420, Gnambs i Hanfstingl, 2016, str. 1705).

Na temelju ovoga istraživanja i mnogih drugih spomenutih u ovome radu koja tvrde da korištenje tehnologije pozitivno utječe na usvajanje nastavnih sadržaja, potrebno je promijeniti nastavni plan i program kako bi se učionički svijet uskladio s vanjskim svijetom. Također je potrebno imati jasno definiranu teoriju koja omogućuje nastavnicima da se intelektualno posvete promjenama (Cain, 2004, str. 219). Oni moraju biti upoznati s najnovijim metodama poučavanja tako što će ih učiti, testirati i konačno ih prilagoditi potrebama svoga okruženja.

Rezultati istraživanja daju osnovu za daljnja istraživanja usmjerena na učenike, kao korisnike novih tehnologija u nastavi Glazbene kulture s aspekta njihovih potreba i motivacije za korištenjem ove vrste obrazovanja i nastavnika kao organizatora nastavnoga procesa. Mlađim je učenicima općenito lakše prihvaćati nove nastavne sadržaje tako da su obično fleksibilniji u smislu prihvaćanja novih, inovativnih alata za rad kao što je SGT. Međutim, budući da je primjena novih tehnologija u nastavi Glazbene kulture od velike važnosti za nastavni proces, kako su pokazali rezultati ovoga istraživanja, ona bi trebala imati još važniju ulogu u stjecanju znanja učenika na satima glazbe bez obzira na njihovu dob i kompetencije. 